\title{
GSTM1 Modulation of IL-8 Expression in Human Bronchial Epithelial Cells Exposed to Ozone
}

\author{
Weidong $\mathbf{W u}^{1,2,{ }^{*}}$, Vinod Doreswamy ${ }^{1}$, David Diaz-Sanchez ${ }^{3}$, James M. Samet ${ }^{3}$, Matt Kesic ${ }^{2}$, \\ Lisa Dailey ${ }^{3}$, Wenli Zhang ${ }^{2}$, llona Jaspers ${ }^{1,2}$, and David B. Peden ${ }^{1,2}$ \\ ${ }^{1}$ Department of Pediatrics, University of North Carolina, Chapel Hill, NC 27599, USA \\ ${ }^{2}$ Center for Environmental Medicine, Asthma, and Lung Biology, University of North Carolina, \\ Chapel Hill, NC 27599, USA \\ ${ }^{3}$ Environmental Public Health Division, National Health and Environmental Effects Research \\ Laboratory, US Environmental Protection Agency, Chapel Hill, NC 27599
}

\begin{abstract}
Exposure to the major air pollutant ozone can aggravate asthma and other lung diseases. Our recent study in human volunteers has shown that the glutathione S-transferase mu 1 (GSTM1) null genotype is associated with increased airway neutrophilic inflammation induced by inhaled ozone. The aim of this study was to examine the effect of GSTM1 modulation on interleukin 8 (IL-8) production in ozone-exposed human bronchial epithelial cells (BEAS-2B) and the underlying mechanisms. Exposure of BEAS-2B cells to $0.4 \mathrm{ppm}$ ozone for $4 \mathrm{~h}$ significantly increased IL-8 release with a modest reduction in intracellular reduced glutathione (GSH). Ozone exposure induced reactive oxygen species (ROS) production and NFKB activation. Pharmacological inhibition of $\mathrm{NF} \kappa \mathrm{B}$ activation or mutation of $I L-8$ promoter at $\kappa B$-binding site significantly blocked ozone-induced IL-8 production or $I L-8$ transcriptional activity, respectively. Knockdown of GSTM1 in BEAS-2B cells enhanced ozone-induced NFאB activation and IL-8 production. Consistently, ozone-induced overt increase in IL-8 production was detected in GSTM1-null primary human bronchial epithelial cells. In addition, supplementation with reduced GSH inhibited ozone-induced ROS production, NFKB activation and IL-8 production. Taken together, GSTM1 deficiency enhances ozone-induced IL-8 production, which is mediated by generated ROS and subsequent NFKB activation in human bronchial epithelial cells.
\end{abstract}

\section{Keywords}

ozone; IL-8; GSTM1; human bronchial epithelial cells; ROS; NFאB

\section{Introduction}

Ozone is one of the most abundant components of air pollution in urban areas and is thought to act, in part, as an inducer of airway inflammation (1-4). This agent is generated at ground

\footnotetext{
(C) 2011 Elsevier Inc. All rights reserved.

*Corresponding author: Weidong Wu, Ph.D., Center for Environmental Medicine, Asthma, and Lung Biology, University of North Carolina, 104 Mason Farm Road, Chapel Hill, NC 27599, Tel. (919)8432714, Fax. (919)9669863, Weidong_Wu@ med.unc.edu.

Publisher's Disclaimer: This is a PDF file of an unedited manuscript that has been accepted for publication. As a service to our customers we are providing this early version of the manuscript. The manuscript will undergo copyediting, typesetting, and review of the resulting proof before it is published in its final citable form. Please note that during the production process errors may be discovered which could affect the content, and all legal disclaimers that apply to the journal pertain.
} 
level by photochemical reactions involving nitrogen dioxide, oxygen, hydrocarbons, and ultraviolet (UV) radiation. Human activities are major sources of ozone precursors, although the latter are also generated by nonanthropogenic processes (5). Increased outdoor levels of ozone have been associated with an increased risk of admissions for asthma, chronic obstructive pulmonary disease and increased mortality in patients with asthma and the general population (6-10). Controlled inhalation studies of both asthmatic and nonasthmatic adults have revealed an acute decrease in lung function, enhanced allergeninduced bronchoconstriction and increases in airway inflammation typified by increased influx of neutrophils after ozone challenge (11-16). However, the mechanisms underlying ozone-induced airway inflammation have not been fully elucidated.

Airway inflammation is a central feature of many respiratory diseases. The specific characteristics of the inflammatory response in each disease and the site of inflammation differ but all involve the recruitment and activation of inflammatory cells and changes in the structural cells of the lung. These conditions are characterized by an increased expression of the inflammatory mediators including cytokines, chemokines, growth factors, enzymes, receptors and adhesion molecules (17). The airway epithelium represents the interface between the external environment and tissue of the airway wall. The production of proinflammatory mediators from airway epithelial cells exposed to environmental irritants plays a critical role in the pathogenesis of airway disorders, such as asthma (18). Among these pro-inflammatory mediators, interleukin 8 (IL-8) is a potent neutrophil activator and chemotaxin and often used as a biological marker of environmentally induced pulmonary inflammation (19-21). Ozone inhalation induces human airway epithelial damage and increased release of pro-inflammatory mediators including IL-8 in bronchoalveolar lavage fluids (BALF) $(22,23)$. In vitro exposure of human bronchial epithelial cells to ozone increases IL-8 production (24-26). In this study, we used IL-8 as the biomarker of ozoneinduced airway inflammation and explored the regulatory events in ozone-induced IL-8 expression in human bronchial epithelial cells.

The toxicological effects of ozone are affected by many factors. In addition to the concentration and duration of exposure and co-existence of other air pollutants $(4,27-29)$, host susceptibility factors play a key role in determining the risk for ozone-induced airway inflammation. Ozone is a strong pro-oxidant and reacts with the epithelial lining fluid to generate free radicals (30). Genetic association studies of ozone exposure in humans have revealed an association between polymorphisms in oxidative stress genes such as glutathione-S-transferase MI (GSTM1), and exacerbation of asthma (31). Asthmatic children with GSTM1 null and GSTP1 valine/valine genotypes appear more susceptible to developing respiratory symptoms related to ozone exposure (32). Furthermore, a clinical trial showed that children with asthma with the low antioxidant GSTMI genotype had a fall in lung function with increasing ozone concentration, unless protected by antioxidant supplementation with vitamins $\mathrm{C}$ and $\mathrm{E}$ (33). We recently reported that GSTM1 null volunteers had significantly increased airway neutrophils after ozone challenge compared to GSTM1 sufficient volunteers, although nociceptive decreases in pulmonary function was similar between these groups (34). It should be noted that these in vivo studies only investigated the association of GSTM1 genotype with pollutant-induced lung inflammation, and they cannot exclude contribution of other genetic factors in modulation of response to ozone. To our knowledge, no mechanistic studies have been conducted to examine the function of GSTM1 protein in the pathogenesis of airway inflammation. Given the key role IL-8 plays in neutrophil chemotaxis, this study specifically examined the effect of deficient GSTM1 protein expression on ozone-induced IL-8 expression in human bronchial epithelial cells. 


\section{Materials and methods}

\section{Reagents}

Triton X-100, polyacrylamide and glutathione ethyl ester (GSH-ET) were purchased from Sigma Chemical Co. (St. Louis, MO). SDS-PAGE supplies such as molecular mass standards and buffers were from Bio-Rad (Richmond, CA). 5-(and-6)-carboxy-2', 7'dichlorodihydrofluorescein diacetate (carboxy- $\mathrm{H}_{2}$ DCFDA) was purchased from Invitrogen Corporation (Carlsbad, CA). Bay11-7082 was obtained from EMD Chemicals Inc. (Gibbstown, NJ). IאB $\alpha$ antibody and horseradish peroxidase (HRP)-conjugated goat antirabbit antibody were obtained from Santa Cruz Biotechnology (Santa Cruz, CA). ßactin antibody was purchased from USBiological (Swampscott, MA). Lactate dehydrogenase (LDH) cytotoxicity detection kit was obtained from TAKARA Bio Inc. (Mountain View, CA). QuantiChrom ${ }^{\mathrm{TM}}$ GSH assay kit was obtained from BioAssay Systems (Hayward, CA). Rabbit anti-human GSTM1 antibody and GST activity assay kit was purchased from Cayman Chemical Company (Ann Arbor, MI). IL-8 ELISA assay kit was purchased from eBioscience (San Diego, CA). Chemiluminescence reagents, expression arrest GIPZ lentiviral GSTM1 shRNA particles and non-silencing control shRNA particles were obtained from Thermo Scientific (Huntsville, AL).

\section{Cell culture and ozone exposure}

BEAS-2B cell line: The BEAS-2B cell line was derived by transforming human bronchial epithelial cells with an adenovirus 12 -simian virus 40 construct $(35,36)$. BEAS-2B cells (passages 70-80) were cultured in keratinocyte basal medium (KBM) supplemented with 30 $\mu \mathrm{g} / \mathrm{ml}$ bovine pituitary extract, $5 \mathrm{ng} / \mathrm{ml}$ human epidermal growth factor (EGF), $500 \mathrm{ng} / \mathrm{ml}$ hydrocortisone, $0.1 \mathrm{mM}$ ethanolamine, $0.1 \mathrm{mM}$ phosphoethanolamine, and $5 \mathrm{ng} / \mathrm{ml}$ insulin (keratinocyte growth medium, KGM). $3 \times 10^{5}$ BEAS-2B cells were placed on collagencoated filter supports (transwell insert) with a $0.4 \mu \mathrm{m}$ pore size (Costar, Cambridge, MA) and grown overnight. The culture medium on the apical side of the transwell was removed immediately before BEAS-2B cells were exposed to sterile air or $0.4 \mathrm{ppm}$ ozone for $4 \mathrm{~h}$ in the exposure chambers operated by the US Environmental Protection Agency Environmental Public Health Division.

Normal human bronchial epithelial (NHBE) cells were obtained from normal adult human volunteers with the GSTM1-null or sufficient genotype by brush biopsy of the mainstem bronchus using a cytology brush during fiberoptic bronchoscopy, conducted under a protocol approved by the Committee on the Protection of the Rights of Human Subjects at the University of North Carolina at Chapel Hill. NHBE cells were initially plated in supplemented bronchial epithelial cell basal medium $(0.5 \mathrm{ng} / \mathrm{ml}$ human EGF, $0.5 \mu \mathrm{g} / \mathrm{ml}$ hydrocortisone, $5 \mu \mathrm{g} / \mathrm{ml}$ insulin, $10 \mu \mathrm{g} / \mathrm{ml}$ transferrin, $0.5 \mu \mathrm{g} / \mathrm{ml}$ epinephrine, $6.5 \mathrm{ng} / \mathrm{ml}$ triiodothyronine, $50 \mu \mathrm{g} / \mathrm{ml}$ gentamycin, $50 \mathrm{ng} / \mathrm{ml}$ amphotericin-B, $52 \mu \mathrm{g} / \mathrm{ml}$ bovine pituitary extract and $0.1 \mathrm{ng} / \mathrm{ml}$ retinoic acid) on tissue culture flasks. Confluent cells were split and placed on the transwell before ozone exposure.

\section{Measurement of intracellular reduced GSH}

BEAS-2B cells were exposed to $0.4 \mathrm{ppm}$ ozone for $4 \mathrm{~h}$. The cells were scraped off the transwell and lysed by sonication in the cold buffer containing $50 \mathrm{mM} \mathrm{MEP}(\mathrm{pH}=7)$ and 1 $\mathrm{mM}$ EDTA. The cell lysates were centrifuged at $10,000 \mathrm{~g}$ for $15 \mathrm{~min}$ at $4^{\circ} \mathrm{C}$. The supernatants were subjected to intracellular GSH measurement following the manufacturer's instruction. 


\section{Measurement of LDH levels in culture medium}

BEAS-2B cells were exposed to $0.4 \mathrm{ppm}$ ozone for $4 \mathrm{~h}$. The cell culture medium from the basolateral chamber of air-liquid interface culture system was collected for the measurement of LDH concentration according to the manufacturer's instruction. Released LDH content was expressed as optical density (OD).

\section{Enzyme linked immunosorbent assay (ELISA)}

After exposure of BEAS-2B cells to $0.4 \mathrm{ppm}$ ozone for $4 \mathrm{~h}$, the culture medium from the basolateral compartment of the transwell unit was collected and centrifuged. Levels of IL-8 protein in the supernatants were measured with a human IL-8 ELISA kit following the manufacturer's instructions.

\section{Immunoblotting}

BEAS-2B cells exposed to sterile air or ozone were washed twice with ice-cold phosphatebuffered saline (PBS), and then lysed in RIPA buffer ( $1 \times$ PBS, $1 \%$ nonidet P-40, $0.5 \%$ sodium deoxycholate, $0.1 \%$ SDS, and protease inhibitors: $20 \mu \mathrm{g} / \mathrm{ml}$ leupeptin, $20 \mu \mathrm{g} / \mathrm{ml}$ aprotinin, $0.5 \mathrm{mM}$ phenylmethylsulfonyl fluoride, $200 \mu \mathrm{M}$ sodium orthovanadate, and 20 $\mathrm{mM}$ sodium fluoride). The supernatants of cell lysates were subjected to SDS-PAGE. Proteins were transferred onto nitrocellulose membrane. Membrane was blocked with 5\% nonfat milk, washed briefly, incubated with primary antibody at $4^{\circ} \mathrm{C}$ overnight, followed by incubating with corresponding HRP-conjugated secondary antibody for $1 \mathrm{~h}$ at room temperature. Immunoblot images were detected using chemiluminescence reagents and the Fujifilm LAS-3000 imaging system (Fuji Medical Systems, USA).

\section{GSTM1 knockdown assay}

$5 \times 10^{4}$ BEAS-2B cells were placed in a 12 well plate and grown overnight. 10 moi (multiplicity of infection) of lentiviral non-silencing (scrambled) or GSTM1 shRNA particles in $0.5 \mathrm{ml} \mathrm{KBM}$ were incubated with BEAS-2B cells for $6 \mathrm{~h}$. Then $0.5 \mathrm{ml} \mathrm{KGM}$ was added into the infection medium and incubated for another $18 \mathrm{~h}$. Confluent BEAS-2B cells were lysed and assayed for GSTM1 protein levels using immunoblotting.

\section{Real-time reverse transcriptase/polymerase chain reaction (RT-PCR)}

BEAS-2B cells expressing wild-type or mutated ( $\kappa$ B-binding site) $I L-8$ promoter-conjugated firefly luciferase ( $f L C F$ ) construct, and enhanced green fluorescent protein (EGFP) construct (37) were exposed to sterile air or $0.4 \mathrm{ppm}$ ozone for $4 \mathrm{~h}$, respectively. The cells were lysed with TRIZOL reagent (Invitrogen Corporation, Carlsbad, CA). Total RNA (100 ng), $0.5 \mathrm{mM}$ NTP (Pharmacia, Piscataway, NJ), $5 \mu \mathrm{M}$ random hexaoligonucleotide primers (Pharmacia, NJ), $10 \mathrm{U} / \mu \mathrm{l}$ RNase inhibitor (Promega, CA), and $10 \mathrm{U} / \mu \mathrm{l}$ Moloney murine leukemia virus RT (GIBCO-BRL Life Technologies) were incubated in a $40^{\circ} \mathrm{C}$ water bath for $1 \mathrm{~h}$ in $50 \mu \mathrm{l}$ of $1 \times \mathrm{PCR}$ buffer to synthesize first-strand cDNAs. The reverse transcription was inactivated by heating at $92^{\circ} \mathrm{C}$ for $5 \mathrm{~min}$. Oligonucleotide primer pairs and fluorescent probes for $f L C F$ and $E G F P$ were designed and obtained from Integrated DNA Technologies (Coralville, IA). Quantitative fluorogenic amplification of cDNA was performed using the ABI Prism 7500 Sequence Detection System (Perkin-Elmer, CA). The relative abundance of fLCF mRNA levels was calculated using the difference between the cycle threshold (CT) of the $f L C F$ mRNA sequence and the reference EGFP mRNA sequence.

\section{Measurement of intracellular reactive oxygen species (ROS)}

The intracellular formation of ROS in BEAS-2B cells was detected using the fluorescent ROS probe carboxy- $\mathrm{H}_{2}$ DCFDA. Carboxy- $\mathrm{H}_{2}$ DCFDA is a cell-permeant indicator for ROS that is nonfluorescent until the acetate groups are removed by intracellular esterases and 
oxidation occurs within the cell (38). The green fluorescence produced by BEAS-2B cells is proportional to the amount of ROS produced. Briefly, confluent BEAS-2B cells were preincubated with $20 \mu \mathrm{M}$ carboxy- $\mathrm{H}_{2}$ DCFDA at $37^{\circ} \mathrm{C}$ for $1 \mathrm{~h}$ prior to exposure to $0.4 \mathrm{ppm}$ ozone for $4 \mathrm{~h}$. Cells were detached by $0.05 \%$ trypsin-EDTA, washed once with PBS, suspended in $0.5 \mathrm{ml}$ PBS and put on ice before determination of green fluorescence intensity. Flow cytometry was performed with a FACSORT (Becton-Dickinson, Miami, FL, USA) by using an argon-ion laser (wavelength $488 \mathrm{~nm}$ ). The FACSORT was calibrated with Calibrite beads before each use, and 6000 events were counted for all sample runs. Relative cell size and density/granularity were quantified by analyzing light-scatter properties using CellQuest software (Becton-Dickinson), namely forward scatter for cell size and side scatter for density/granularity, and recording the mean fluorescence intensities for each.

\section{GSTM1 activity assay}

NHBE cells from human volunteers with the GSTM1-null or -sufficient genotype were suspended into the sample buffer ( $100 \mathrm{mM}$ potassium phosphatases, pH6.5, containing $0.1 \%$ Triton X-100 and $1 \mathrm{mM}$ glutathione). The cells were broken down with sonication and the supernatants subjected to immuoprecipitation. Specifically, $5 \mu \mathrm{l}$ of rabbit anti-human GSTM1 antibody was incubated with the supernatant at $4^{\circ} \mathrm{C}$ for $2 \mathrm{~h}$ prior to addition of $10 \mu \mathrm{l}$ Protein A-agarose and incubated at $4^{\circ} \mathrm{C}$ overnight. The immunoprecitates were washed with cold PBS three times before determination of GST activity following the manufacturer's instructions.

\section{Statistical analysis}

Data were presented as means $\pm \mathrm{SE}$ and evaluated using nonparametric paired $t$ tests with the overall $\alpha$ level set at 0.05 .

\section{Results}

\section{Ozone exposure induces increased IL-8 production as well as cell damage to human bronchial epithelial cells}

The overproduction of IL-8 is a biomarker of airway inflammation $(39,40)$. In vivo and in vitro studies have shown that ozone exposure elevates IL-8 protein levels in BALF or culture medium (22-26). Since ozone effect is concentration- and time-dependent, and cell type-specific (41), we examined IL-8 production in BEAS-2B cells exposed to $0.4 \mathrm{ppm}$ ozone for $4 \mathrm{~h}$ referred to our recent in vivo study (16). Levels of IL-8 protein in the supernatant of culture medium were determined using ELISA. As shown in Figure 1A, ozone exposure significantly increased IL-8 protein release from BEAS-2B cells as compared to control (sterile air). As expected, the positive control IL-1 $\beta(10 \mathrm{ng} / \mathrm{ml})$ induced a pronounced increase in IL-8 production from BEAS-2B cells (Figure 1A).

Under the same exposure condition, the cytotoxicity of ozone exposure was assessed by assay of LDH activity in the culture medium. It was shown that ozone stimulation significantly elevated LDH levels in the culture medium of BEAS-2B cells compared to air (Figure 1B). This result indicated that exposure to $0.4 \mathrm{ppm}$ ozone for $4 \mathrm{~h}$ could cause cell injury, which was consistent with previous observation (42).

\section{Ozone exposure induces ROS production that can be inhibited by supplementation of reduced GSH}

Ozone is a highly reactive gas associated with oxidative stress (43). ROS production has been shown in ozone-exposed guinea pig airway epithelial cells and human BALF cells (44, 45). To examine whether ozone challenge increased ROS production in BEAS-2B cells, the fluorogenic probe carboxy- $\mathrm{H}_{2}$ DCFDA was used. As demonstrated in Figure 2A, exposure of 
BEAS-2B cells to $0.4 \mathrm{ppm}$ ozone for $4 \mathrm{~h}$ resulted in increased ROS production in BEAS-2B cells. To determine whether ROS production could be inhibited by antioxidant, we next employed the reduced GSH (GSH-ET) to pretreat BEAS-2B cells prior to ozone exposure. As shown in Figure 2B, pre-incubation of BEAS-2B cells with $10 \mathrm{mM}$ GSH-ET for $1 \mathrm{~h}$ modestly inhibited ozone-induced ROS production, indicating that reduced GSH is an antagonist of ROS induced by ozone stimulation.

\section{Ozone-induced reduction of intracellular reduced GSH and its association with IL-8 production}

The fact that supplementation of reduced GSH inhibited ozone-induced ROS production implied that ozone exposure might affect intracellular reduced GSH levels. To test this assumption, the intracellular reduced GSH levels were measured after ozone treatment $(0.4$ ppm ozone for $4 \mathrm{~h}$ ). As shown in Figure 3A, ozone exposure induced a modest reduction in intracellular reduced GSH levels. To further examine the association of intracellular GSH with ozone-induced IL-8 expression, BEAS-2B cells were pre-incubated with $10 \mathrm{mM} \mathrm{GSH}-$ ET for $1 \mathrm{~h}$ before exposure to ozone. The medium containing GSH-ET on the apical side of the transwell was removed just before ozone exposure, but the GSH-ET remained in the basolateral culture medium. Levels of IL-8 protein in the culture supernatant of basolateral medium were measured as described previously. As expected, in the vehicle group ozone exposure increased IL-8 production (Figure 3B). In contrast, GSH-ET pretreatment markedly inhibited ozone-induced IL-8 release from BEAS-2B cells. These results suggested that reduction of intracellular reduced GSH could result in ozone-induced IL-8 production.

In addition, GSH-ET supplementation was also shown to inhibit ozone-induced cell toxicity (Data not shown).

\section{GSTM1 knockdown enhances ozone-induced IL-8 production}

GSTM1 has been detected in the brush border of proximal airways as well as in alveolar cells and macrophages (46). Our recent in vivo study has revealed that GSTMI null genotype is associated with increased neutrophilic airway inflammation after ozone exposure (34). Since IL-8 is a potent neutrophil chemokine we hypothesized that GSTM1 homeostasis is associated with the expression levels of IL-8 in ozone-treated human bronchial epithelial cells. To examine this hypothesis, we modulated intracellular GSTM1 levels in BEAS-2B cells with lentiviral GSTM1 shRNA particles and then compared the difference in IL-8 production from BEAS-2B cells expressing adequate or deficient GSTM1 after ozone challenge. Infection of BEAS-2B cells with 10 moi of lentiviral GSTM1 shRNA particles caused significant reduction of GSTM1 protein levels (by 82\%) in BEAS-2B cells as compared to the cells infected with scrambled lentiviral shRNA particles (Figure 4A). GSTM1 adequate or deficient (knockdown) cells were further treated with air or $0.4 \mathrm{ppm}$ ozone for $4 \mathrm{~h}$ and IL-8 levels in the culture supernatants measured. In the cells expressing scrambled shRNA ozone stimulation increased IL-8 production from BEAS-2B cells (Figure 4B). In the cells expressing GSTMI shRNA ozone-induced IL-8 production was further increased by GSTM1 knockdown (Figure 4B).

To further verify the observation in BEAS-2B cells, we next used normal human bronchial epithelial cells from volunteers with the GSTM1-null or -sufficient genotype to determine the association of GSTM1 with IL-8 production after ozone exposure. GSTM1 activity was first examined in the NHBE cells with the GSTM1-null or sufficient genotype using immunoprecipitation. As expected, GSTM1 activity was not detected in GSTM1-null NHBE cells. In contrast, GSTM1 enzymatic activity was detected in GSTM1-sufficient NHBE cells (Figure 4C). Furthermore, Ozone exposure ( $0.4 \mathrm{ppm}, 4 \mathrm{~h})$ induced a significant increase in 
IL-8 production from the cells with GSTM1-null genotype than that from the GSTM1sufficient bronchial epithelial cells (Figure 4D). As shown in BEAS-2B cells, IL-1 (10 ng/ $\mathrm{ml}$ ) significantly increased IL-8 production from normal human bronchial epithelial cells (data not shown).

\section{NFKB activation is required for ozone-induced IL-8 production}

Activation of the transcription factor NFKB is required for $I L-8$ gene transcription in many cell types (47). To examine whether ozone stimulation activated NFKB, degradation of the $\mathrm{NF} \kappa \mathrm{B}$ inhibitory protein $\kappa \mathrm{B} \alpha(\mathrm{I} \kappa \mathrm{B} \alpha)$, an event indicative of the canonical NFKB-activating pathway (48), was determined. BEAS-2B cells were exposed to $0.4 \mathrm{ppm}$ ozone for 30 and $60 \mathrm{~min}$. I $\mathrm{B} \alpha$ levels in the cell lysates were measured using immunoblotting. As shown in Figure 5A, exposure of BEAS-2B cells to ozone for $30 \mathrm{~min}$ had minimal effect on IкB $\alpha$ levels. However, at $60 \mathrm{~min}$ exposure to ozone, the I $\mathrm{K} B \alpha$ levels dropped significantly in compared to those of control, indicating that ozone exposure could activate NFkB at $60 \mathrm{~min}$ exposure. To further examine whether NFKB was involved in ozone-induced IL-8 production, Bay11-7082, a specific and potent inhibitor of NFKB activation that inhibits the phosphorylation and degradation of I $\mathrm{B} \alpha$ and subsequent nuclear translocation of $\mathrm{p} 65$ and p50 (49), was used prior to ozone treatment. BEAS-2B cells were pre-incubated with $20 \mu \mathrm{M}$ Bay11-7082 for 60 min before further challenged with $0.4 \mathrm{ppm}$ ozone for $4 \mathrm{~h}$. As shown in Figure 5B, Bay 11-7082 pretreatment abolished ozone-induced IL-8 production, implying that NFKB was required for ozone-induced IL-8 production. To support this notion, BEAS-2B cells expressing wild-type or mutated ( $\kappa \mathrm{B}$-binding site) $I L-8$ promoter-conjugated $f L C F$, and $E G F P$ constructs were employed. Levels of $f L C F$ mRNA are proportional to the transcriptional activities of $I L-8$ promoter. As demonstrated in Figure 5C, ozone exposure increased $f L C F$ mRNA levels in the cells encoding wild-type $I L-8$ promoter (IL-8wt). However, this effect of ozone exposure was significantly reduced in the cells containing mutated ( $\kappa B$-binding site) $I L-8$ promoter (IL- $8 \mathrm{mNF} \kappa \mathrm{B}$ ). Taken together, these results indicate that ozone exposure activates $\mathrm{NF \kappa B}$, which is required for ozone-induced $I L-8$ gene expression in human bronchial epithelial cells.

\section{GSTM1 modulate ozone-induced NFKB activation}

As demonstrated previously, both GSTM1 and NFאB were involved in the regulation of ozone-induced IL- 8 production from BEAS-2B cells. We next examined the possible association of GSTM1 with NFKB in ozone-induced IL-8 production. BEAS-2B cells were infected with lentiviral scrambled or GSTM1 shRNA particles, respectively, as described previously. As shown in Figure 6A, in the cells expressing scrambled shRNA, ozone exposure induced marked I $\mathrm{B} \alpha$ degradation. In contrast, in the cells encoding GSTMI shRNA the IкB $\alpha$ levels went even lower than those in the cells containing scrambled shRNA after ozone exposure, which indicated that GSTM1 knockdown enhanced ozone-induced $\mathrm{NF \kappa B}$ activation. Consistent with this observation, the antioxidant GSH-ET supplementation

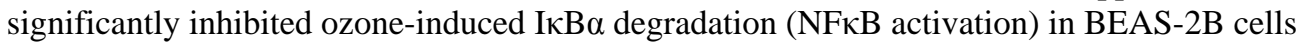
(Figure 6B).

\section{Discussion}

GSTM1 belongs to a family of dimeric phase II metabolic enzymes known to catalyze the conjugation of reduced GSH with electrophilic compounds such as products of oxidative stress (50). GSTMI has been mapped to the GST mu gene cluster on chromosome 1p13.3. Deletion variants or null alleles exist for the GSTM1 gene present biochemically as a failure to express protein (51-55). The GSTM null genotype has been associated with increased risk for adverse health effects due to exposure to air pollutants $(56,57)$. Our recent study showed that the GSTM1 null genotype was associated with increased airway inflammation after 
ozone exposure (34). Consistent with this observation, we now report that silencing of GSTM1 with shRNA for GSTMI in human bronchial epithelial cell line or GSTM1-null genotype of normal human bronchial epithelial cells is associated with ozone-induced overproduction of IL-8. It should be noted that the methodology used in this study is limited due to the usage of transformed epithelial cells incubated without the protection of respiratory tract lining fluids and in artificial culture media.

The results from this study indicate that GSTM1 modulation of IL-8 production from ozonetreated BEAS-2B cells involves NFKB and ROS. We found that silencing of GSTM1 enhances ozone-induced NFאB activation, which can be inhibited by supplementation with reduced GSH, the substrate of GSTM1, demonstrating that GSTM1 modulates NFkB activation. NFkB is a family of highly regulated dimeric transcription factors that play pivotal roles in inflammatory responses and immunological reactions. Five members of the

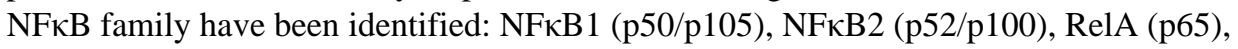
RelB, and c-Rel (58). In mammals, the NFkB transcription factor consists of two subunits of either homo- or heterodimers of RelA/p65, c-Rel, and p50. The p50/RelA(p65) heterodimer is the major Rel/NFKB complex in most cell types (59). NFkB can be activated through two pathways, the classical (canonical) and alternative pathways. In the classic pathway,

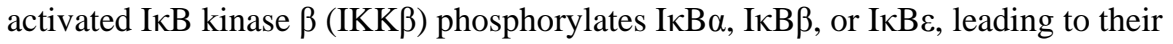
proteasomal degradation. As a result, NFKB homodimers and heterodimers accumulate in the nucleus and regulate the expression of its target genes such as those coding for cytokines, adhesion molecules and chemokines that have a crucial role in both immune and inflammatory responses (60-62). The alternative NFKB pathway is responsible for the activation of p100/RelB complexes and occurs during lymphoid development (63). The promoter region of human $I L-8$ gene contains a number of potential binding sites for several inducible transcription factors including NFKB, activator protein-1 (AP-1), and CAAT/ enhancer-binding protein (C/EBP) (64-66). The expression of $I L-8$ gene is regulated primarily at the level of transcription $(66,67)$. Unlike the AP-1 and C/EBP sites, the NFkB site is essential for induction and required for maximal gene expression of $I L-8$ gene (68). The data from this study shows that NFKB is required for ozone-induced IL-8 production.

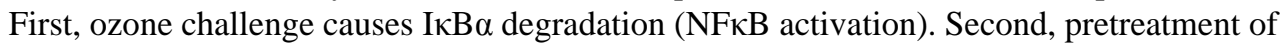
BEAS-2B cells with the specific NFאB activation inhibitor Bay11-7082 abolishes ozoneinduced IL- 8 production. Third, mutation of $\kappa B$-binding site on the $I L-8$ promoter causes significant reduction of $I L-8$ promoter transcription activity. Moreover, these results also suggest that ozone exposure induces NFKB activation through the classic pathway since Bay11-7082, a specific and potent inhibitor of the classic NFkB activation pathway (69), significantly blocks ozone-induced IL-8 production.

This study further indicates that GSTM1 modulates ozone-induced NFKB activation and subsequent IL-8 production in BEAS-2B cells through GSH-regulated ROS production although previous studies on the association of ROS generation with NFKB activation have produced controversial results (70-75). As described previously, GSTM1 exerts its antioxidant effect by conjugating reduced GSH with electrophilic ROS. Evidence in support of ROS-mediated NFkB activation in ozone-exposed cells includes 1.) Observations that ozone exposure increases ROS production from BEAS-2B cells along with the reduction of intracellular reduced GST; 2.) Supplementation of antioxidant GSH blocks ozone-induced I $\kappa \mathrm{B} \alpha$ degradation (NFKB activation) and IL-8 production and; 3.) Knockdown of antioxidant GSTM1 from BEAS-2B cells enhances NFKB activation and IL-8 production. ROS include superoxide anion, hydroxyl radical, organic peroxide radicals, hydrogen peroxide, and singlet molecular oxygen (76). They are constantly generated intracellularly in eukaryotic cells as products of mitochondrial electron transfer chain reactions, and upon exposure to different environmental stimuli, such as UV light and inflammatory cytokines $(77,78)$. It has been speculated that increased ROS production by human bronchial epithelial cells may 
result from increased activity of the microbicidal oxidase, increased mitochondrial activity, an increased oxidizing environment in the cytoplasm, or a decrease in cellular scavengers of ROS after ozone treatment $(45,79)$. As for the mechanisms of ROS-mediated NFkB activation, previous studies have shown that Syk-mediated phosphorylation of IкB $\alpha$ and p65 (80), and activation of IKK (81) are involved in hydrogen peroxide-induced NFKB activation. In addition, c-Src has been shown to modulate ROS-induced NFKB activation (82).

In summary, consistent with our recent in vivo study, this in vitro study using human bronchial epithelial cells confirms that GSTM1 is a risk factor for ozone-induced inflammatory responses. Specifically, knockdown of GSTM1 leads to enhanced IL-8 production from human bronchial epithelial cells exposed to ozone, which is verified in GSTM1-null normal human bronchial epithelial cells. Furthermore, this study demonstrates that GSTM1 modulation of IL-8 production involves ROS-regulated NFkB activation. Since the GSTM1 null genotype occurs at high frequency in most ethnic populations (55), characterization of the GSTM1contribution to air pollution-induced inflammatory lung diseases and underlying mechanisms provides fundamental information for the design of preventive and therapeutic measures against air pollutant-related pulmonary disorders.

\section{Acknowledgments}

This work was supported by grants U19AI077437 from the National Institute of Allergy and Infectious Diseases, RC1ES018417 and R01ES016535 from the National Institute of Environmental Health Sciences. The content is solely the responsibility of the authors and does not necessarily represent the official views of the National Institute of Environmental Health Sciences and the National Institute of Allergy and Infectious Diseases. None of the authors has any competing financial interests.

\section{List of Abbreviations}

$\begin{array}{ll}\text { GSTM1 } & \text { glutathione S-transferase mu 1 } \\ \text { IL-8 } & \text { interleukin } 8 \\ \text { ROS } & \text { reactive oxygen species } \\ \text { EGF } & \text { epidermal growth factor } \\ \text { BALF } & \text { bronchoalveolar lavage fluids } \\ \text { GSH-ET } & \text { glutathione ethyl ester } \\ \text { HRP } & \text { horseradish peroxidase } \\ \text { KBM } & \text { keratinocyte basal medium } \\ \text { LDH } & \text { lactate dehydrogenase } \\ \text { KGM } & \text { keratinocyte growth medium } \\ \text { ELISA } & \text { enzyme linked immunosorbent assay } \\ \text { PBS } & \text { phosphate-buffered saline } \\ \text { RT-PCR } & \text { real-time reverse transcriptase/polymerase chain reaction } \\ \text { EGFP } & \text { green fluorescent protein } \\ \text { moi } & \text { multiplicity of infection } \\ \text { fLCF } & \text { firefly luciferase } \\ \text { IKB } \alpha & \text { inhibitory protein } \kappa \text { B } \alpha\end{array}$




$\begin{array}{ll}\text { NFкB } & \text { nuclear factor } \kappa \mathrm{B} \\ \text { TNF } & \text { tumor necrosis factor } \\ \text { UV } & \text { ultraviolet }\end{array}$

\section{References}

1. Peden DB, Setzer RW Jr, Devlin RB. Ozone exposure has both a priming effect on allergen-induced responses and an intrinsic inflammatory action in the nasal airways of perennially allergic asthmatics. Am J Respir Crit Care Med. 1995; 151:1336-1345. [PubMed: 7735583]

2. McConnell R, Berhane K, Gilliland F, London SJ, Islam T, Gauderman WJ, Avol E, Margolis HG, Peters JM. Asthma in exercising children exposed to ozone: a cohort study. Lancet. 2002; 359:386391. [PubMed: 11844508]

3. Lin S, Liu X, Le LH, Hwang SA. Chronic exposure to ambient ozone and asthma hospital admissions among children. Environ Health Perspect. 2008; 116:1725-1730. [PubMed: 19079727]

4. D'Amato G, Cecchi L, D'Amato M, Liccardi G. Urban air pollution and climate change as environmental risk factors of respiratory allergy: an update. J Investig Allergol Clin Immunol. 2010; 20:95-102. quiz following 102.

5. Brook RD, Franklin B, Cascio W, Hong Y, Howard G, Lipsett M, Luepker R, Mittleman M, Samet J, Smith SC Jr, Tager I. Air pollution and cardiovascular disease: a statement for healthcare professionals from the Expert Panel on Population and Prevention Science of the American Heart Association. Circulation. 2004; 109:2655-2671. [PubMed: 15173049]

6. Sunyer J, Basagana X, Belmonte J, Anto JM. Effect of nitrogen dioxide and ozone on the risk of dying in patients with severe asthma. Thorax. 2002; 57:687-693. [PubMed: 12149528]

7. Bell ML, McDermott A, Zeger SL, Samet JM, Dominici F. Ozone and short-term mortality in 95 US urban communities, 1987-2000. Jama. 2004; 292:2372-2378. [PubMed: 15547165]

8. Gryparis A, Forsberg B, Katsouyanni K, Analitis A, Touloumi G, Schwartz J, Samoli E, Medina S, Anderson HR, Niciu EM, Wichmann HE, Kriz B, Kosnik M, Skorkovsky J, Vonk JM, Dortbudak Z. Acute effects of ozone on mortality from the "air pollution and health: a European approach" project. Am J Respir Crit Care Med. 2004; 170:1080-1087. [PubMed: 15282198]

9. Medina-Ramon M, Zanobetti A, Schwartz J. The effect of ozone and PM10 on hospital admissions for pneumonia and chronic obstructive pulmonary disease: a national multicity study. Am J Epidemiol. 2006; 163:579-588. [PubMed: 16443803]

10. Filleul L, Cassadou S, Medina S, Fabres P, Lefranc A, Eilstein D, Le Tertre A, Pascal L, Chardon B, Blanchard M, Declercq C, Jusot JF, Prouvost H, Ledrans M. The relation between temperature, ozone, and mortality in nine French cities during the heat wave of 2003. Environ Health Perspect. 2006; 114:1344-1347. [PubMed: 16966086]

11. Holz O, Jorres RA, Timm P, Mucke M, Richter K, Koschyk S, Magnussen H. Ozone-induced airway inflammatory changes differ between individuals and are reproducible. Am J Respir Crit Care Med. 1999; 159:776-784. [PubMed: 10051250]

12. Jorres RA, Holz O, Zachgo W, Timm P, Koschyk S, Muller B, Grimminger F, Seeger W, Kelly FJ, Dunster C, Frischer T, Lubec G, Waschewski M, Niendorf A, Magnussen H. The effect of repeated ozone exposures on inflammatory markers in bronchoalveolar lavage fluid and mucosal biopsies. Am J Respir Crit Care Med. 2000; 161:1855-1861. [PubMed: 10852757]

13. Alexis NE, Becker S, Bromberg PA, Devlin R, Peden DB. Circulating CD11b expression correlates with the neutrophil response and airway $\mathrm{mCD} 14$ expression is enhanced following ozone exposure in humans. Clin Immunol. 2004; 111:126-131. [PubMed: 15093561]

14. Alexis NE, Lay JC, Haczku A, Gong H, Linn W, Hazucha MJ, Harris B, Tal-Singer R, Peden DB. Fluticasone propionate protects against ozone-induced airway inflammation and modified immune cell activation markers in healthy volunteers. Environ Health Perspect. 2008; 116:799-805. [PubMed: 18560537]

15. Alexis NE, Lay JC, Hazucha M, Harris B, Hernandez ML, Bromberg PA, Kehrl H, Diaz-Sanchez D, Kim C, Devlin RB, Peden DB. Low-level ozone exposure induces airways inflammation and 
modifies cell surface phenotypes in healthy humans. Inhal Toxicol. 2010; 22:593-600. [PubMed: 20384440]

16. Hernandez ML, Harris B, Lay JC, Bromberg PA, Diaz-Sanchez D, Devlin RB, Kleeberger SR, Alexis NE, Peden DB. Comparative airway inflammatory response of normal volunteers to ozone and lipopolysaccharide challenge. Inhal Toxicol. 2010; 22:648-656. [PubMed: 20540623]

17. Adcock IM, Chung KF, Caramori G, Ito K. Kinase inhibitors and airway inflammation. Eur J Pharmacol. 2006; 533:118-132. [PubMed: 16469308]

18. Holgate ST. The airway epithelium is central to the pathogenesis of asthma. Allergol Int. 2008; 57:1-10. [PubMed: 18209502]

19. Kunkel SL, Standiford T, Kasahara K, Strieter RM. Interleukin-8 (IL-8): the major neutrophil chemotactic factor in the lung. Exp Lung Res. 1991; 17:17-23. [PubMed: 2013270]

20. Standiford TJ, Kunkel SL, Strieter RM. Interleukin-8: a major mediator of acute pulmonary inflammation. Reg Immunol. 1993; 5:134-141. [PubMed: 8240932]

21. Strieter RM. Interleukin-8: a very important chemokine of the human airway epithelium. Am J Physiol Lung Cell Mol Physiol. 2002; 283:L688-689. [PubMed: 12225944]

22. Krishna MT, Madden J, Teran LM, Biscione GL, Lau LC, Withers NJ, Sandstrom T, Mudway I, Kelly FJ, Walls A, Frew AJ, Holgate ST. Effects of 0.2 ppm ozone on biomarkers of inflammation in bronchoalveolar lavage fluid and bronchial mucosa of healthy subjects. Eur Respir J. 1998; 11:1294-1300. [PubMed: 9657569]

23. Bosson J, Stenfors N, Bucht A, Helleday R, Pourazar J, Holgate ST, Kelly FJ, Sandstrom T, Wilson S, Frew AJ, Blomberg A. Ozone-induced bronchial epithelial cytokine expression differs between healthy and asthmatic subjects. Clin Exp Allergy. 2003; 33:777-782. [PubMed: 12801312]

24. Devlin RB, McKinnon KP, Noah T, Becker S, Koren HS. Ozone-induced release of cytokines and fibronectin by alveolar macrophages and airway epithelial cells. Am J Physiol. 1994; 266:L612619. [PubMed: 8023949]

25. Rusznak C, Devalia JL, Sapsford RJ, Davies RJ. Ozone-induced mediator release from human bronchial epithelial cells in vitro and the influence of nedocromil sodium. Eur Respir J. 1996; 9:2298-2305. [PubMed: 8947075]

26. Bayram H, Sapsford RJ, Abdelaziz MM, Khair OA. Effect of ozone and nitrogen dioxide on the release of proinflammatory mediators from bronchial epithelial cells of nonatopic nonasthmatic subjects and atopic asthmatic patients in vitro. J Allergy Clin Immunol. 2001; 107:287-294. [PubMed: 11174195]

27. McDonnell WF, Stewart PW, Andreoni S, Seal E Jr, Kehrl HR, Horstman DH, Folinsbee LJ, Smith MV. Prediction of ozone-induced FEV1 changes. Effects of concentration, duration, and ventilation. Am J Respir Crit Care Med. 1997; 156:715-722. [PubMed: 9309984]

28. Noyes PD, McElwee MK, Miller HD, Clark BW, Van Tiem LA, Walcott KC, Erwin KN, Levin ED. The toxicology of climate change: environmental contaminants in a warming world. Environ Int. 2009; 35:971-986. [PubMed: 19375165]

29. Molhave L, Kjaergaard SK, Sigsgaard T, Lebowitz M. Interaction between ozone and airborne particulate matter in office air. Indoor Air. 2005; 15:383-392. [PubMed: 16268828]

30. Kelly FJ, Mudway IS. Protein oxidation at the air-lung interface. Amino Acids. 2003; 25:375-396. [PubMed: 14661098]

31. David GL, Romieu I, Sienra-Monge JJ, Collins WJ, Ramirez-Aguilar M, del Rio-Navarro BE, Reyes-Ruiz NI, Morris RW, Marzec JM, London SJ. Nicotinamide adenine dinucleotide (phosphate) reduced:quinone oxidoreductase and glutathione S-transferase M1 polymorphisms and childhood asthma. Am J Respir Crit Care Med. 2003; 168:1199-1204. [PubMed: 12969868]

32. Romieu I, Ramirez-Aguilar M, Sienra-Monge JJ, Moreno-Macias H, del Rio-Navarro BE, David G, Marzec J, Hernandez-Avila M, London S. GSTM1 and GSTP1 and respiratory health in asthmatic children exposed to ozone. Eur Respir J. 2006; 28:953-959. [PubMed: 16870661]

33. Romieu I, Sienra-Monge JJ, Ramirez-Aguilar M, Moreno-Macias H, Reyes-Ruiz NI, Estela del Rio-Navarro B, Hernandez-Avila M, London SJ. Genetic polymorphism of GSTM1 and antioxidant supplementation influence lung function in relation to ozone exposure in asthmatic children in Mexico City. Thorax. 2004; 59:8-10. [PubMed: 14694237] 
34. Alexis NE, Zhou H, Lay JC, Harris B, Hernandez ML, Lu TS, Bromberg PA, Diaz-Sanchez D, Devlin RB, Kleeberger SR, Peden DB. The glutathione-S-transferase Mu 1 null genotype modulates ozone-induced airway inflammation in human subjects. J Allergy Clin Immunol. 2009; 124:1222-1228. e1225. [PubMed: 19796798]

35. Wu W, Silbajoris RA, Cao D, Bromberg PA, Zhang Q, Peden DB, Samet JM. Regulation of cyclooxygenase-2 expression by cAMP response element and mRNA stability in a human airway epithelial cell line exposed to zinc. Toxicol Appl Pharmacol. 2008; 231:260-266. [PubMed: 18513776]

36. Reddel RR, Ke Y, Gerwin BI, McMenamin MG, Lechner JF, Su RT, Brash DE, Park JB, Rhim JS, Harris CC. Transformation of human bronchial epithelial cells by infection with SV40 or adenovirus-12 SV40 hybrid virus, or transfection via strontium phosphate coprecipitation with a plasmid containing SV40 early region genes. Cancer Res. 1988; 48:1904-1909. [PubMed: 2450641]

37. Tal TL, Simmons SO, Silbajoris R, Dailey L, Cho SH, Ramabhadran R, Linak W, Reed W, Bromberg PA, Samet JM. Differential transcriptional regulation of IL-8 expression by human airway epithelial cells exposed to diesel exhaust particles. Toxicol Appl Pharmacol. 2010; 243:4654. [PubMed: 19914270]

38. Cathcart R, Schwiers E, Ames BN. Detection of picomole levels of hydroperoxides using a fluorescent dichlorofluorescein assay. Anal Biochem. 1983; 134:111-116. [PubMed: 6660480]

39. Woodin MA, Hauser R, Liu Y, Smith TJ, Siegel PD, Lewis DM, Tollerud DJ, Christiani DC. Molecular markers of acute upper airway inflammation in workers exposed to fuel-oil ash. Am J Respir Crit Care Med. 1998; 158:182-187. [PubMed: 9655727]

40. Bodini A, D'Orazio C, Peroni D, Corradi M, Folesani G, Baraldi E, Assael BM, Boner A, Piacentini GL. Biomarkers of neutrophilic inflammation in exhaled air of cystic fibrosis children with bacterial airway infections. Pediatr Pulmonol. 2005; 40:494-499. [PubMed: 16229003]

41. Ahmad S, Ahmad A, McConville G, Schneider BK, Allen CB, Manzer R, Mason RJ, White CW. Lung epithelial cells release ATP during ozone exposure: signaling for cell survival. Free Radic Biol Med. 2005; 39:213-226. [PubMed: 15964513]

42. Gabrielson EW, Yu XY, Spannhake EW. Comparison of the toxic effects of hydrogen peroxide and ozone on cultured human bronchial epithelial cells. Environ Health Perspect. 1994; 102:972974. [PubMed: 9738213]

43. Lippmann M. Health effects of tropospheric ozone: review of recent research findings and their implications to ambient air quality standards. J Expo Anal Environ Epidemiol. 1993; 3:103-129. [PubMed: 8518544]

44. Chen LC, Qu Q. Formation of intracellular free radicals in guinea pig airway epithelium during in vitro exposure to ozone. Toxicol Appl Pharmacol. 1997; 143:96-101. [PubMed: 9073597]

45. Voter KZ, Whitin JC, Torres A, Morrow PE, Cox C, Tsai Y, Utell MJ, Frampton MW. Ozone exposure and the production of reactive oxygen species by bronchoalveolar cells in humans. Inhal Toxicol. 2001; 13:465-483. [PubMed: 11445887]

46. Cantlay AM, Smith CA, Wallace WA, Yap PL, Lamb D, Harrison DJ. Heterogeneous expression and polymorphic genotype of glutathione S- transferases in human lung. Thorax. 1994; 49:10101014. [PubMed: 7974294]

47. Villarete LH, Remick DG. Transcriptional and post-transcriptional regulation of interleukin-8. Am J Pathol. 1996; 149:1685-1693. [PubMed: 8909257]

48. Ghosh S, Karin M. Missing pieces in the NF-kappaB puzzle. Cell. 2002; 109(Suppl):S81-96. [PubMed: 11983155]

49. Goffi F, Boroni F, Benarese M, Sarnico I, Benetti A, Spano PF, Pizzi M. The inhibitor of I kappa B alpha phosphorylation BAY 11-7082 prevents NMDA neurotoxicity in mouse hippocampal slices. Neurosci Lett. 2005; 377:147-151. [PubMed: 15755516]

50. Hayes JD, Pulford DJ. The glutathione S-transferase supergene family: regulation of GST and the contribution of the isoenzymes to cancer chemoprotection and drug resistance. Crit Rev Biochem Mol Biol. 1995; 30:445-600. [PubMed: 8770536] 
51. Pemble S, Schroeder KR, Spencer SR, Meyer DJ, Hallier E, Bolt HM, Ketterer B, Taylor JB. Human glutathione S-transferase theta (GSTT1): cDNA cloning and the characterization of a genetic polymorphism. Biochem J. 1994; 300(Pt 1):271-276. [PubMed: 8198545]

52. Board PG. Biochemical genetics of glutathione-S-transferase in man. Am J Hum Genet. 1981; 33:36-43. [PubMed: 7468592]

53. Seidegard J, Vorachek WR, Pero RW, Pearson WR. Hereditary differences in the expression of the human glutathione transferase active on trans-stilbene oxide are due to a gene deletion. Proc Natl Acad Sci U S A. 1988; 85:7293-7297. [PubMed: 3174634]

54. Spurdle AB, Webb PM, Purdie DM, Chen X, Green A, Chenevix-Trench G. Polymorphisms at the glutathione S-transferase GSTM1, GSTT1 and GSTP1 loci: risk of ovarian cancer by histological subtype. Carcinogenesis. 2001; 22:67-72. [PubMed: 11159743]

55. Geisler SA, Olshan AF. GSTM1, GSTT1, and the risk of squamous cell carcinoma of the head and neck: a mini-HuGE review. Am J Epidemiol. 2001; 154:95-105. [PubMed: 11447041]

56. Peden DB. The epidemiology and genetics of asthma risk associated with air pollution. J Allergy Clin Immunol. 2005; 115:213-219. quiz 220. [PubMed: 15696070]

57. London SJ. Gene-air pollution interactions in asthma. Proc Am Thorac Soc. 2007; 4:217-220. [PubMed: 17607002]

58. Hayden MS, Ghosh S. Shared principles in NF-kappaB signaling. Cell. 2008; 132:344-362. [PubMed: 18267068]

59. Gilmore TD. The Rel/NF-kappaB signal transduction pathway: introduction. Oncogene. 1999; 18:6842-6844. [PubMed: 10602459]

60. Zandi E, Karin M. Bridging the gap: composition, regulation, and physiological function of the IkappaB kinase complex. Mol Cell Biol. 1999; 19:4547-4551. [PubMed: 10373503]

61. Karin M, Ben-Neriah Y. Phosphorylation meets ubiquitination: the control of NF-[kappa]B activity. Annu Rev Immunol. 2000; 18:621-663. [PubMed: 10837071]

62. Hayden MS, Ghosh S. Signaling to NF-kappaB. Genes Dev. 2004; 18:2195-2224. [PubMed: 15371334]

63. Vallabhapurapu S, Karin M. Regulation and function of NF-kappaB transcription factors in the immune system. Annu Rev Immunol. 2009; 27:693-733. [PubMed: 19302050]

64. Wu GD, Lai EJ, Huang N, Wen X. Oct-1. CCAAT/enhancer-binding protein (C/EBP) bind to overlapping elements within the interleukin-8 promoter. The role of Oct-1 as a transcriptional repressor. J Biol Chem. 1997; 272:2396-2403. [PubMed: 8999951]

65. Luster AD. Chemokines--chemotactic cytokines that mediate inflammation. N Engl J Med. 1998; 338:436-445. [PubMed: 9459648]

66. Roebuck KA. Regulation of interleukin-8 gene expression. J Interferon Cytokine Res. 1999; 19:429-438. [PubMed: 10386854]

67. Holtmann H, Winzen R, Holland P, Eickemeier S, Hoffmann E, Wallach D, Malinin NL, Cooper JA, Resch K, Kracht M. Induction of interleukin- 8 synthesis integrates effects on transcription and mRNA degradation from at least three different cytokine- or stress-activated signal transduction pathways. Mol Cell Biol. 1999; 19:6742-6753. [PubMed: 10490613]

68. Hoffmann E, Dittrich-Breiholz O, Holtmann H, Kracht M. Multiple control of interleukin- 8 gene expression. J Leukoc Biol. 2002; 72:847-855. [PubMed: 12429706]

69. Pierce JW, Schoenleber R, Jesmok G, Best J, Moore SA, Collins T, Gerritsen ME. Novel inhibitors of cytokine-induced IkappaBalpha phosphorylation and endothelial cell adhesion molecule expression show anti-inflammatory effects in vivo. J Biol Chem. 1997; 272:21096-21103. [PubMed: 9261113]

70. Shono T, Ono M, Izumi H, Jimi SI, Matsushima K, Okamoto T, Kohno K, Kuwano M. Involvement of the transcription factor NF-kappaB in tubular morphogenesis of human microvascular endothelial cells by oxidative stress. Mol Cell Biol. 1996; 16:4231-4239. [PubMed: 8754823]

71. Wang Z, Castresana MR, Newman WH. Reactive oxygen and NF-kappaB in VEGF-induced migration of human vascular smooth muscle cells. Biochem Biophys Res Commun. 2001; 285:669-674. [PubMed: 11453645] 
72. Hughes G, Murphy MP, Ledgerwood EC. Mitochondrial reactive oxygen species regulate the temporal activation of nuclear factor kappaB to modulate tumour necrosis factor-induced apoptosis: evidence from mitochondria-targeted antioxidants. Biochem J. 2005; 389:83-89. [PubMed: 15727562]

73. Li Q, Engelhardt JF. Interleukin-1beta induction of NFkappaB is partially regulated by H2O2mediated activation of NFkappaB-inducing kinase. J Biol Chem. 2006; 281:1495-1505. [PubMed: 16286467]

74. Korn SH, Wouters EF, Vos N, Janssen-Heininger YM. Cytokine-induced activation of nuclear factor-kappa B is inhibited by hydrogen peroxide through oxidative inactivation of IkappaB kinase. J Biol Chem. 2001; 276:35693-35700. [PubMed: 11479295]

75. Jaspers I, Zhang W, Fraser A, Samet JM, Reed W. Hydrogen peroxide has opposing effects on IKK activity and IkappaBalpha breakdown in airway epithelial cells. Am J Respir Cell Mol Biol. 2001; 24:769-777. [PubMed: 11415944]

76. Doroshow JH. Role of hydrogen peroxide and hydroxyl radical formation in the killing of Ehrlich tumor cells by anticancer quinones. Proc Natl Acad Sci U S A. 1986; 83:4514-4518. [PubMed: 3086887]

77. Bossi O, Gartsbein M, Leitges M, Kuroki T, Grossman S, Tennenbaum T. UV irradiation increases ROS production via PKCdelta signaling in primary murine fibroblasts. J Cell Biochem. 2008; 105:194-207. [PubMed: 18523985]

78. Das UN, Padma M, Sagar PS, Ramesh G, Koratkar R. Stimulation of free radical generation in human leukocytes by various agents including tumor necrosis factor is a calmodulin dependent process. Biochem Biophys Res Commun. 1990; 167:1030-1036. [PubMed: 2157420]

79. Avissar NE, Reed CK, Cox C, Frampton MW, Finkelstein JN. Ozone, but not nitrogen dioxide, exposure decreases glutathione peroxidases in epithelial lining fluid of human lung. Am J Respir Crit Care Med. 2000; 162:1342-1347. [PubMed: 11029342]

80. Takada Y, Mukhopadhyay A, Kundu GC, Mahabeleshwar GH, Singh S, Aggarwal BB. Hydrogen peroxide activates NF-kappa B through tyrosine phosphorylation of I kappa B alpha and serine phosphorylation of p65: evidence for the involvement of I kappa B alpha kinase and Syk proteintyrosine kinase. J Biol Chem. 2003; 278:24233-24241. [PubMed: 12711606]

81. Yin Z, Ivanov VN, Habelhah H, Tew K, Ronai Z. Glutathione S-transferase p elicits protection against H2O2-induced cell death via coordinated regulation of stress kinases. Cancer Res. 2000; 60:4053-4057. [PubMed: 10945608]

82. Lluis JM, Buricchi F, Chiarugi P, Morales A, Fernandez-Checa JC. Dual role of mitochondrial reactive oxygen species in hypoxia signaling: activation of nuclear factor- $\{$ kappa $\} \mathrm{B}$ via c-SRC and oxidant-dependent cell death. Cancer Res. 2007; 67:7368-7377. [PubMed: 17671207] 

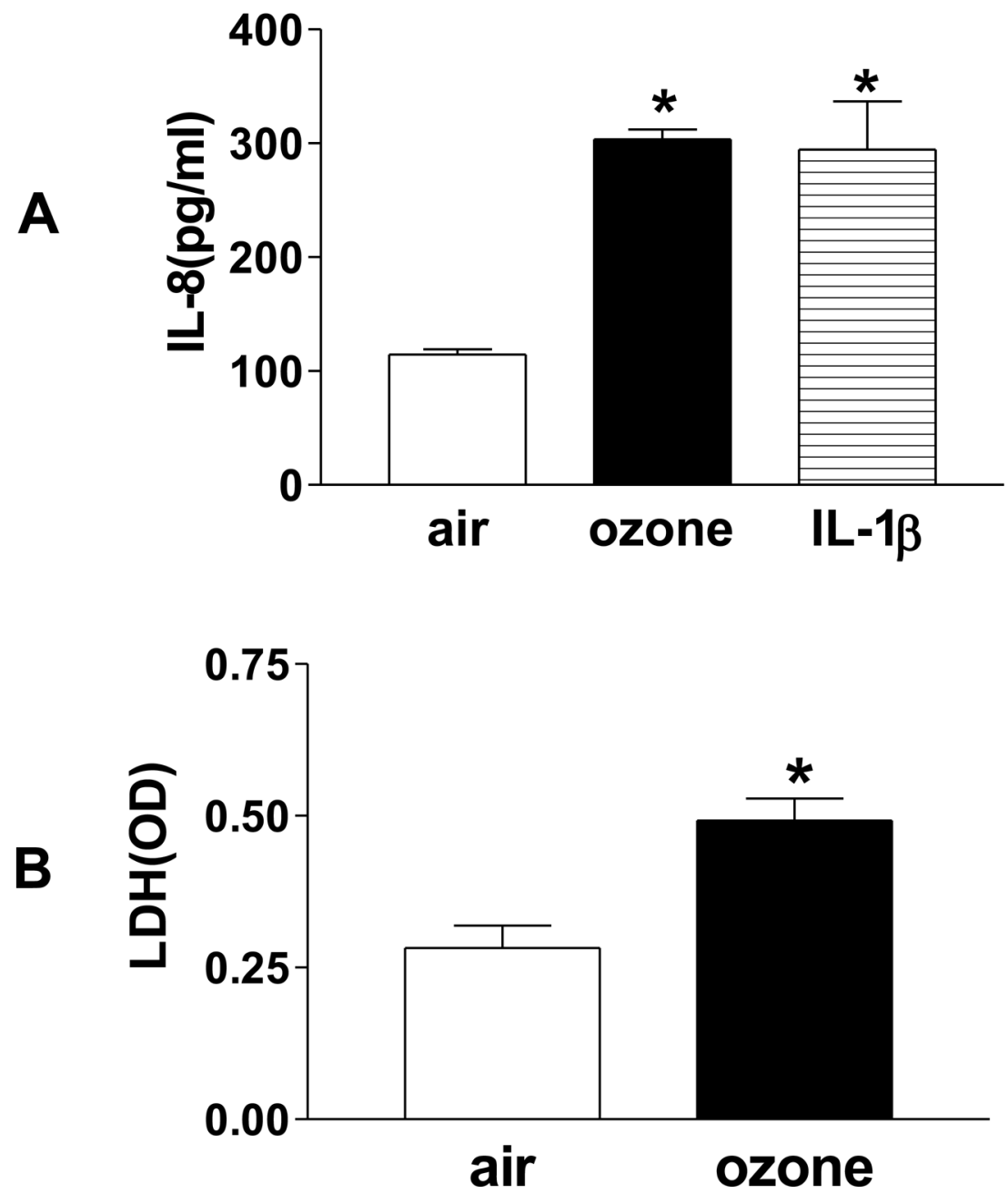

Figure 1. Ozone exposure increases IL-8 and LDH release from BEAS-2B cells Confluent BEAS-2B cells grown on $0.4 \mu \mathrm{m}$ filter supports were exposed to sterile air or 0.4 ppm ozone for $4 \mathrm{~h}$, respectively. IL-8 (A) or LDH (B) levels in the culture medium of the basolateral compartment were measured. IL-1 $\beta(10 \mathrm{ng} / \mathrm{ml}, 24 \mathrm{~h})$ was used as the positive control. *, compared to air, $P<0.05$. 

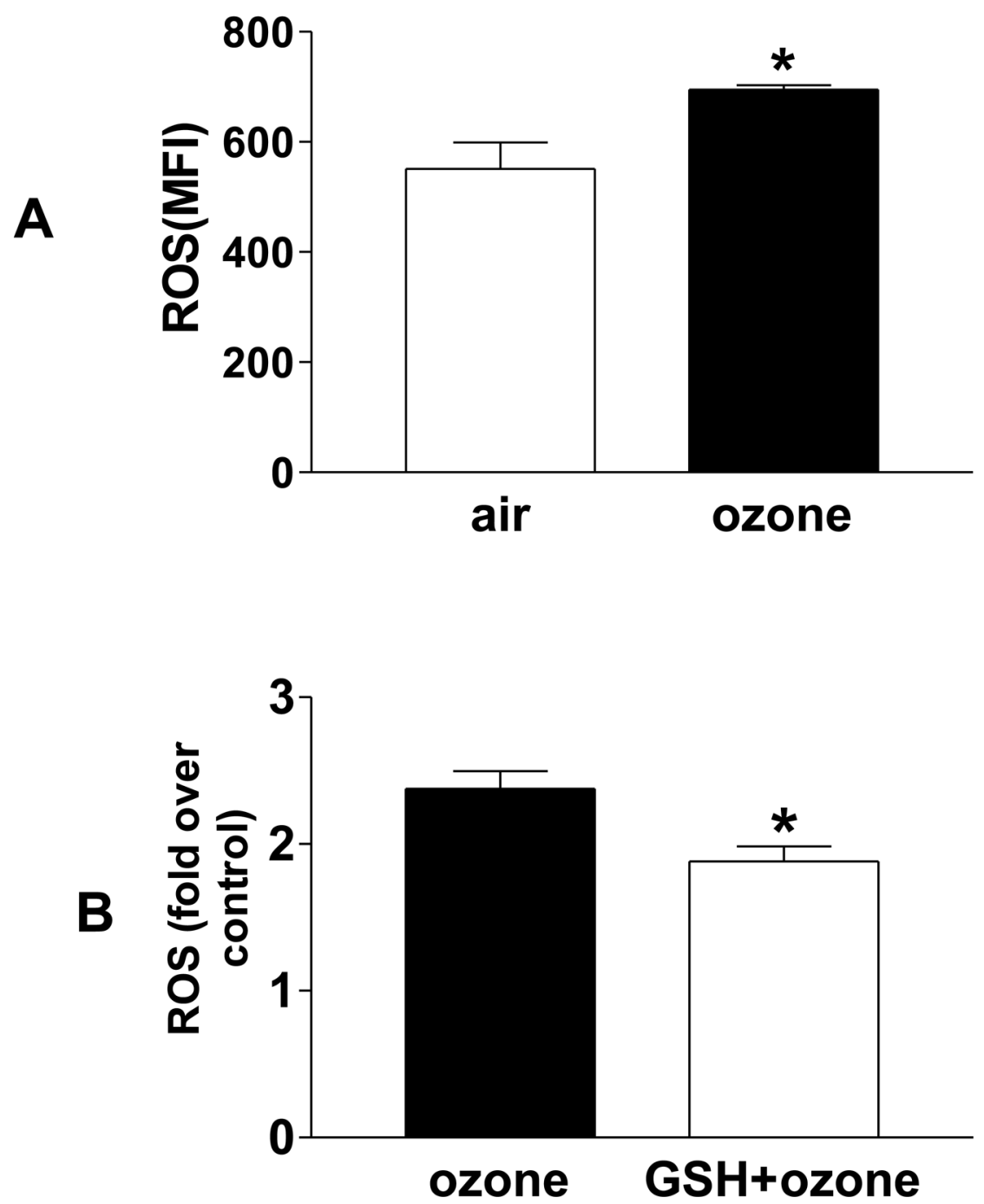

Figure 2. Ozone-induced ROS production is inhibited by GSH supplementation A, BEAS-2B cells were pre-incubated with $20 \mu \mathrm{M}$ carboxy- $\mathrm{H}_{2}$ DCFDA for $1 \mathrm{~h}$, prior to stimulation with 0.4 ppm ozone for $4 \mathrm{~h}$. ROS production was measured with flow cytometry. B, BEAS-2B cells were pre-incubated with $10 \mathrm{mM}$ glutathione ethyl ester (GSH-ET) for 1 $\mathrm{h}$, prior to stimulation with $0.4 \mathrm{ppm}$ ozone for $4 \mathrm{~h}$. ROS was measured as described previously. *, compared to air, $P<0.05$. 

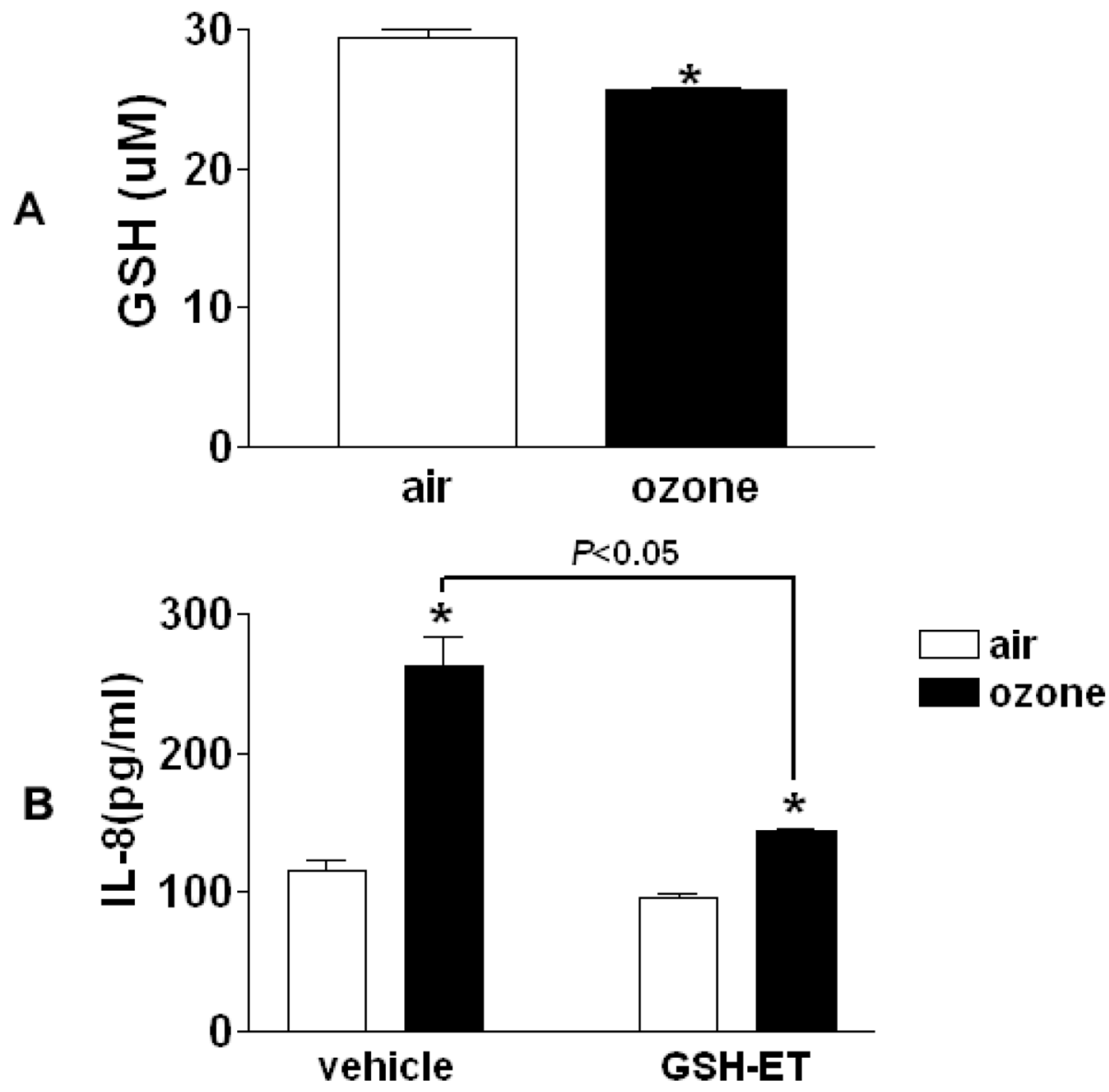

Figure 3. Association of intracellular GSH levels with ozone-induced IL-8 production A, BEAS-2B cells were exposed to $0.4 \mathrm{ppm}$ ozone for $4 \mathrm{~h}$. Intracellular reduced GSH levels were measured. B, BEAS-2B cells were pre-incubated with $10 \mathrm{mM}$ glutathione ethyl ester (GSH-ET) for $1 \mathrm{~h}$, prior to stimulation with $0.4 \mathrm{ppm}$ ozone for $4 \mathrm{~h}$. IL-8 protein levels were measured using ELISA. *, compared to air, $P<0.05$. 
A

shRNA- scramble GSTM1
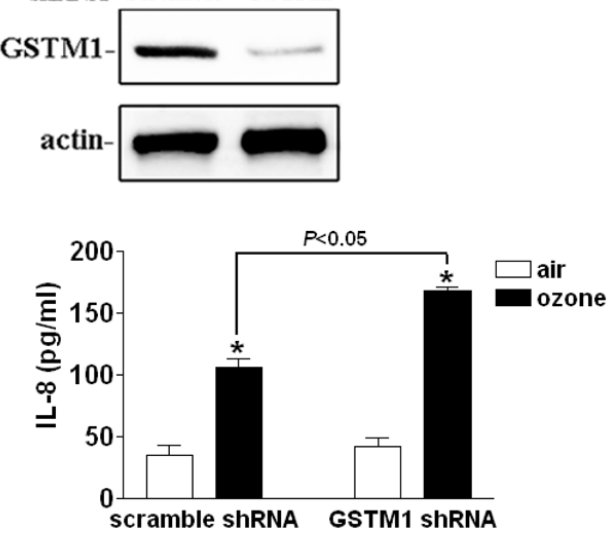

C
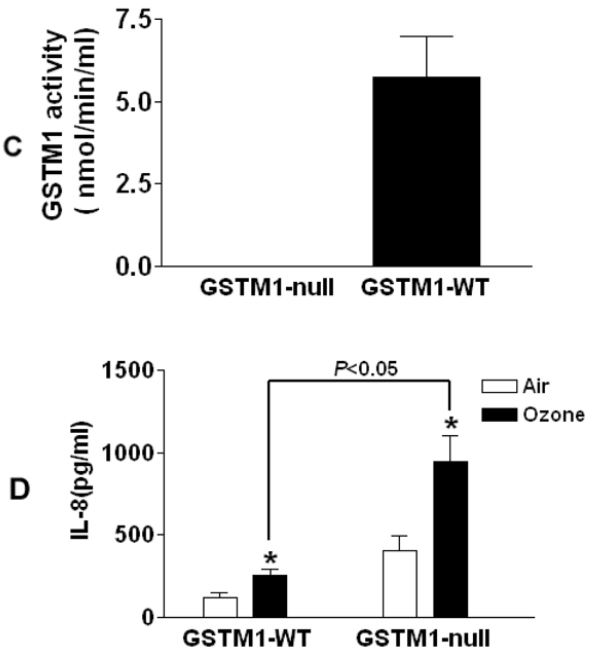

Figure 4. GSTM1 modulation of IL-8 production from human bronchial epithelial cells exposed to ozone

A, BEAS-2B cells were infected with lentiviral scrambled or GSTM1 shRNA particles (MOI=10) for $24 \mathrm{~h}$, respectively. The cells were lysed and GSTM1 protein levels were measured using immunoblotting. B, BEAS-2B cells infected with lentiviral scrambled or GSTM1 shRNA particles were challenged with $0.4 \mathrm{ppm}$ ozone for $4 \mathrm{~h}$. IL-8 protein levels were measured using ELISA. C, Normal human bronchial epithelial cells from volunteers with GSTM1-sufficient (GSTM1-WT) or GSTM1-null genotype (n=3 for each genotype) were assayed for GSTM1 enzymatic activity using immunoprecipitation. D, Normal human bronchial epithelial cells from human volunteers with GSTM1-sufficient (GSTM1-WT) or GSTM1-null genotype (n=5 for each genotype) were exposed to $0.4 \mathrm{ppm}$ ozone for $4 \mathrm{~h}$. IL-8 protein levels were measured as described previously. *, compared to air, $P<0.05$. 

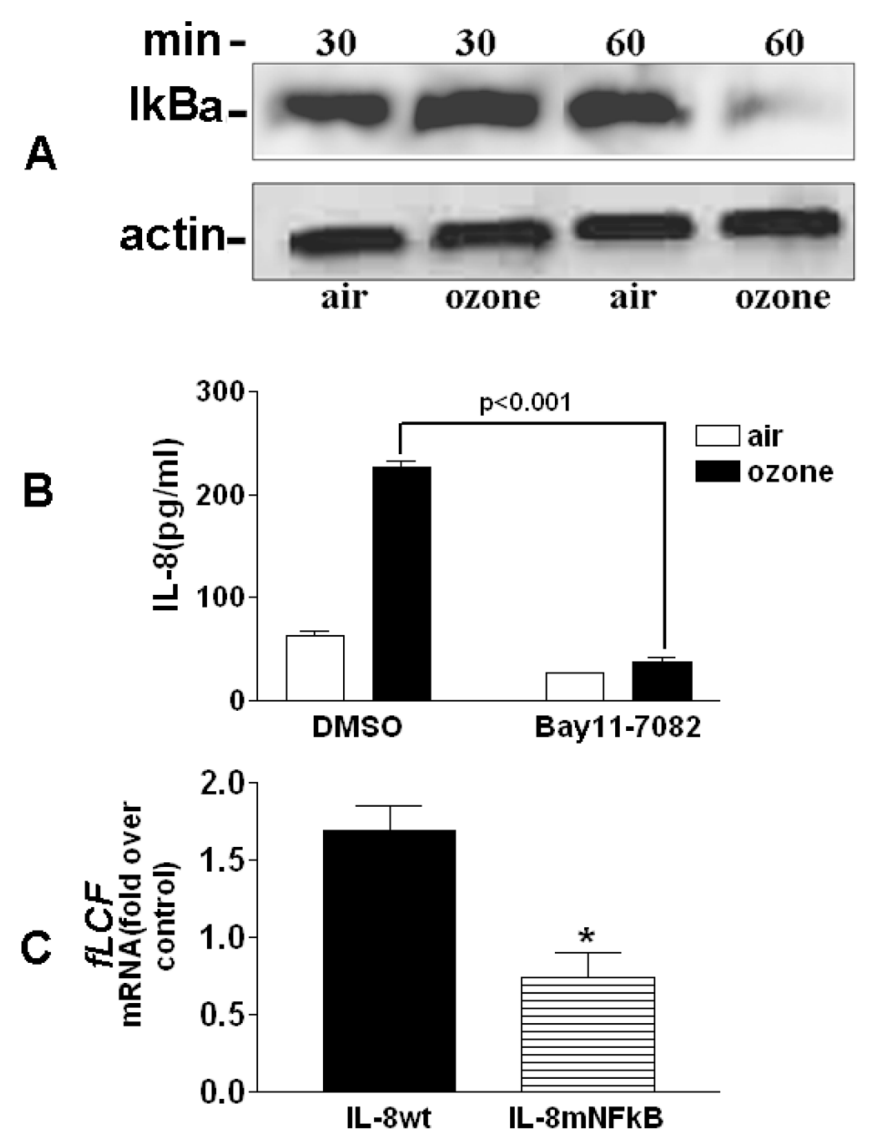

Figure 5. NFкB activation is required for ozone-induced IL-8 production A, BEAS-2B cells were exposed to $0.4 \mathrm{ppm}$ ozone for $30 \mathrm{~min}$ and $60 \mathrm{~min}$. The cells were then lysed with RIPA buffer. The supernatants of the cell lysates were subjected to immunoblotting using I $\mathrm{B} \alpha$ antibody. B, BEAS-2B cells were pretreated with $20 \mu \mathrm{M}$ Bay11-7082 for $1 \mathrm{~h}$ before further stimulated with $0.4 \mathrm{ppm}$ ozone for $4 \mathrm{~h}$. IL- 8 protein levels were measured using ELISA. C, BEAS-2B cells expressing wild-type or $\kappa \mathrm{B}$-binding site mutated $I L-8$ promoter-conjugated $f L C F$, and $E G F P$ constructs were exposed to $0.4 \mathrm{ppm}$ ozone for $4 \mathrm{~h}$. Levels of $f L C F$ mRNA were measured using RT-PCR and normalized with EGFP mRNA levels. *, compared to the cells expressing $I L-8 \mathrm{wt}$ construct exposed to ozone, $P<0.05$. 


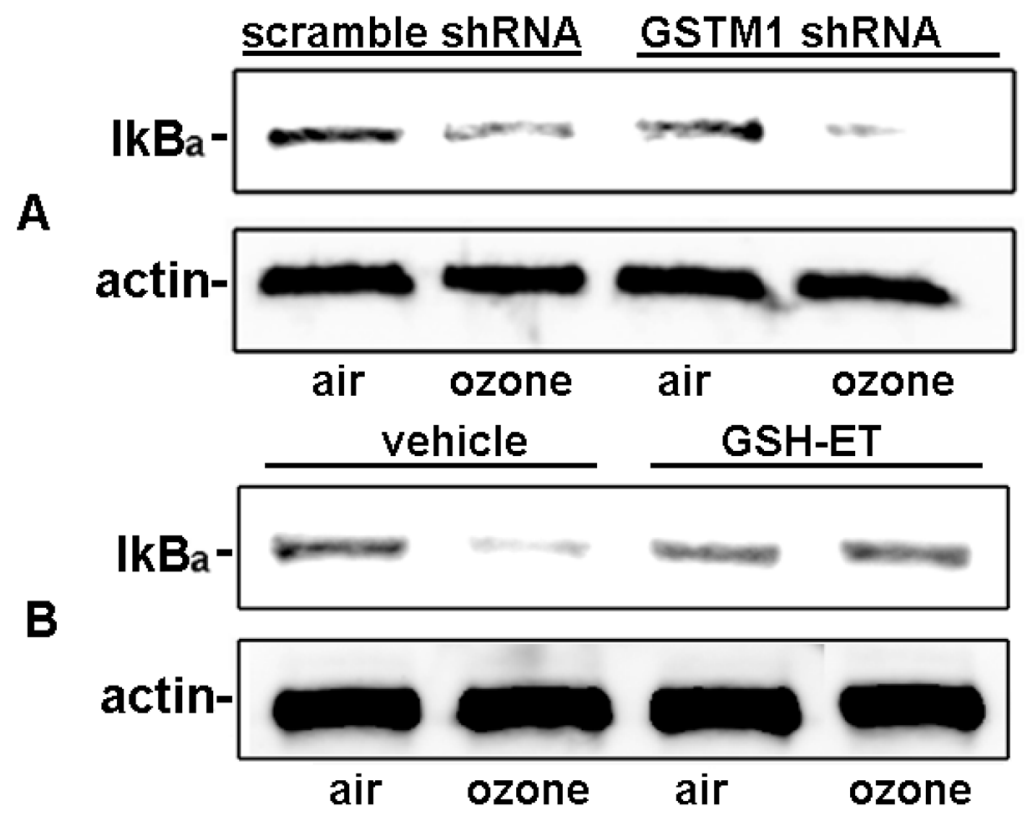

Figure 6. GSTM1 and GSH modulation of NFKB activation in ozone-treated BEAS-2B cells A, Infected BEAS-2B cells with lentiviral scrambled or GSTM1 shRNA particles were challenged with $0.4 \mathrm{ppm}$ ozone for $60 \mathrm{~min}$. The cells were lysed with RIPA buffer and the supernatants of the cell lysates were subjected to immunoblotting using I $\mathrm{B} \alpha$ antibody. B, BEAS-2B cells were incubated with $10 \mathrm{mM} \mathrm{GSH}$-ET for $60 \mathrm{~min}$, prior to stimulation with $0.4 \mathrm{ppm}$ ozone for $60 \mathrm{~min}$. I $\mathrm{B} \alpha$ levels in the supernatants of the cell lysates were measured using immunoblotting. 